\title{
Surgical treatment for a rare case of ectopic tooth in the lateral wall of the nasal cavity
}

\author{
Tratamento cirúrgico de um caso raro de dente ectópico em parede lateral da cavidade nasal \\ Tratamiento quirúrgico de un caso raro de diente ectópico en la pared lateral de la cavidad nasal \\ Manoela Moura DE BORTOLI ${ }^{1}$ \\ José Alcides Almeida de ARRUDA ${ }^{2}$

\begin{abstract}
Among the ways to approach cases of ectopic teeth, the surgical approach is a valid option and should be considered, since it is considered simple and it permits direct visualization and a rapid recovery. The aim of this article is to report a rare case of ectopic tooth in the lateral wall of the nasal cavity caused by trauma in the maxillofacial region in childhood, and to describe its clinical and imaging characteristics as well as ways of treatment and surgical aspects. A 25-year-old woman was seen at the clinic of Maxillofacial Surgery and Traumatology due to the presence of a foreign body in the nose. A treatment plan was elaborated based on physical and radiographic examination. The tooth was removed by a surgical approach and the patient underwent esthetic rehabilitation. Surgical treatment of ectopic teeth provides a good and satisfactory postoperative result, is simple and mostly without complications. Ectopic teeth are rare, and the professional should be able to perform the diagnosis, indication and planning of treatment, as well as its execution. Surgical treatment is an option that produced an effective result in the present case.
\end{abstract}

Descriptors: Mouth; Tooth, Impacted; Ambulatory Surgical Procedures.

\section{Resumo}

Entre as formas de abordagem dos casos de dentes ectópicos, o tratamento cirúrgico é uma opção válida e deve ser considerada, uma vez que é simples e permite a visualização direta e uma rápida recuperação. O objetivo deste artigo é relatar um caso raro de dente ectópico na parede lateral da cavidade nasal, causado por trauma na região maxilofacial na infância, e descrever suas características clínicas e de imagem, bem como formas de tratamento e aspectos cirúrgicos. Paciente do sexo feminino, 25 anos de idade foi atendida na clínica de Cirurgia e Traumatologia Buco Maxilo Facial devido à presença de corpo estranho no nariz. Um plano de tratamento foi elaborado com base no exame físico e radiográfico. O dente foi removido por abordagem cirúrgica e a paciente foi submetido à reabilitação estética. O tratamento cirúrgico dos dentes ectópicos fornece um bom e satisfatório resultado pós-operatório, é simples e na maioria das vezes sem complicações. Os dentes ectópicos são raros e o profissional deve ser capaz de realizar o diagnóstico, a indicação e o planejamento do tratamento, bem como sua execução. $\mathrm{O}$ tratamento cirúrgico foi uma opção que exibiu um resultado efetivo no presente caso.

Descritores: Boca; Dente Impactado; Procedimentos Cirúrgicos Ambulatoriais.

\section{Resumen}

Entre las formas de tratar los casos de dientes ectópicos, el abordaje quirúrgico es una opción válida y que debe ser llevada en consideraión, ya que es considerada simple, permite la visualización directa y oferece una rápida recuperación. El objetivo del presente artículo es relatar un caso raro de diente ectópico en la pared lateral de la cavidad nasal, causado por trauma en la región maxilo facial durante la infancia, y describir sus características clínicas y radiográficas, así como sus formas de tratamiento y aspectos quirúrgicos. Paciente de sexo femenino, de 25 años de edad, fue atendida en la clínica de Cirugía y Traumatología Buco Maxilo Facial debido a la presencia de un cuerpo extraño en la nariz. Un plan de tratamiento fue elaborado con base en el examen físico y radiográfico. El diente fue removido por abordaje quirúrgico y el paciente fue sometido a la rehabilitación estética. El tratamiento quirúrgico de dientes ectópicos proporciona un buen resultado y un postoperatorio satisfactorio, es considerado simple y en la mayoría de veces no tiene complicaciones. Los dientes ectópicos son raros y el Cirujano-Dentista debe estar capacitado para realizar el diagnóstico, indicación y planificación del tratamiento, así como su ejecución. En el presente caso, el tratamiento quirúrgico fue una opción que produjo un resultado efectivo en el paciente.

Descriptores: Boca; Diente Impactado; Procedimientos Quirúrgicos Ambulatorios.

\section{INTRODUCTION}

An ectopic tooth is characterized as an eruption of a tooth in an atypical position or outside the jaw bones. The eruption of teeth at different sites of the oral cavity is uncommon. The incidence of ectopic teeth ranges from 0.1 to $1 \%$ in the general population. Ectopic teeth can be found on the palate, maxillary sinus and floor of the nasal cavity ${ }^{1,2}$.

Traumatic intrusion and lesions in the primary or mixed dentition are the most common causes. Dental ectopy is a condition that can affect the development of the dental arch in terms of dental eruption or even dental crowding ${ }^{3}$. Ectopic teeth are usually unilateral but in rare cases they can be found bilaterally ${ }^{4}$.

The etiology of intranasal teeth is controversial. Many theories have been proposed, including developmental disorders such as cleft palate, trauma-displaced teeth, cysts, infection, obstruction, secondary eruption, dental crowding, persistent deciduous teeth or dense bone $e^{5}$. The condition can affect $11 \%$ of girls and $15 \%$ of boys aged 1 to 12 years, with the first and third years of life being the most common ages of occurrence.

The symptoms vary widely; ectopic teeth can cause pain, nasal obstruction, epistaxis and headache, external deviations of the nose, abscess of the nasal septum and nasal fistula. When asymptomatic they are usually revealed only by routine clinical examination or radiological investigation ${ }^{6-9}$.

An argument for early removal is the 
potential occurrence of severe sequelae such as cavernous sinus thrombosis because the intranasal tooth is situated in the so-called "danger triangle" region of the middle third of the face where veins and valves can drain into the intracranial space ${ }^{5}$. According to Sammatino et al. ${ }^{10}$ (2011), intranasal teeth can be removed by a transnasal access or through the palate. Authors advocate the use of endoscopic extraction for an intranasal tooth. The advantages of such extraction are clear visualization and precise dissection without compromising surrounding structures. Open treatment should also be used as an alternative in the treatment of ectopic teeth, when in posterior intraosseous sites that require direct visualization. This approach is defined with the help of imaging tests, such as X-rays and computed tomography ${ }^{6}$. Therefore, the objective of the present study is to report a case of ectopic tooth in the lateral wall of the nasal cavity and we extensively discuss the symptomatology and treatment options.

\section{CASE REPORT}

A 25-year-old non-white female patient came to the outpatient clinic of Maxillofacial Surgery and Traumatology complaining about a "foreign body in the nose". During anamnesis, the patient reported a trauma that occurred in childhood in the anterior region of the maxilla when she was about 4 years old, with loss of the deciduous tooth. She also reported the absence of permanent tooth eruption. The maxillary facial physical examination showed the presence of a provisional prosthesis with poor aesthetics in the region of the left central incisor and left lateral incisor. She reported the need for removal and the implantodontist suggested graft placement surgery in the anterior region of the maxilla for the installation of implants. The imaging previously requested by another professional, a lateral radiograph of the face (Figure 1), showed the presence of an ectopic tooth in the lateral wall of the nasal cavity region.

The surgical procedure of choice was a surgical approach involving ectopic tooth extraction in a hospital environment under general anesthesia, with nasotracheal intubation on the contralateral side. The access of choice was the vestibular of the maxilla for direct access to the nasal fossa on the left side. After local anesthesia with an agent containing a vasoconstrictor, an incision was made in the left central incisor region to the left premolar, $3 \mathrm{~mm}$ above the mucogingival junction, with a cold scalpel, according to surgeon preference. Detachment was initiated with the aid of periosteal elevators to elevate the subperiosteal plane. First, the infraorbital nerve was identified in the upper planes and posterior to the pyriform aperture region, followed by detachment of the nasal mucosa from the lateral wall of the nasal fossa with Freer's detacher. This allowed retraction and removal of the nasal mucosa, avoiding possible perforation and consequently unwanted bleeding during surgery. The positioning of the tooth on the lateral wall of the left nasal fossa was observed (Figure 2).

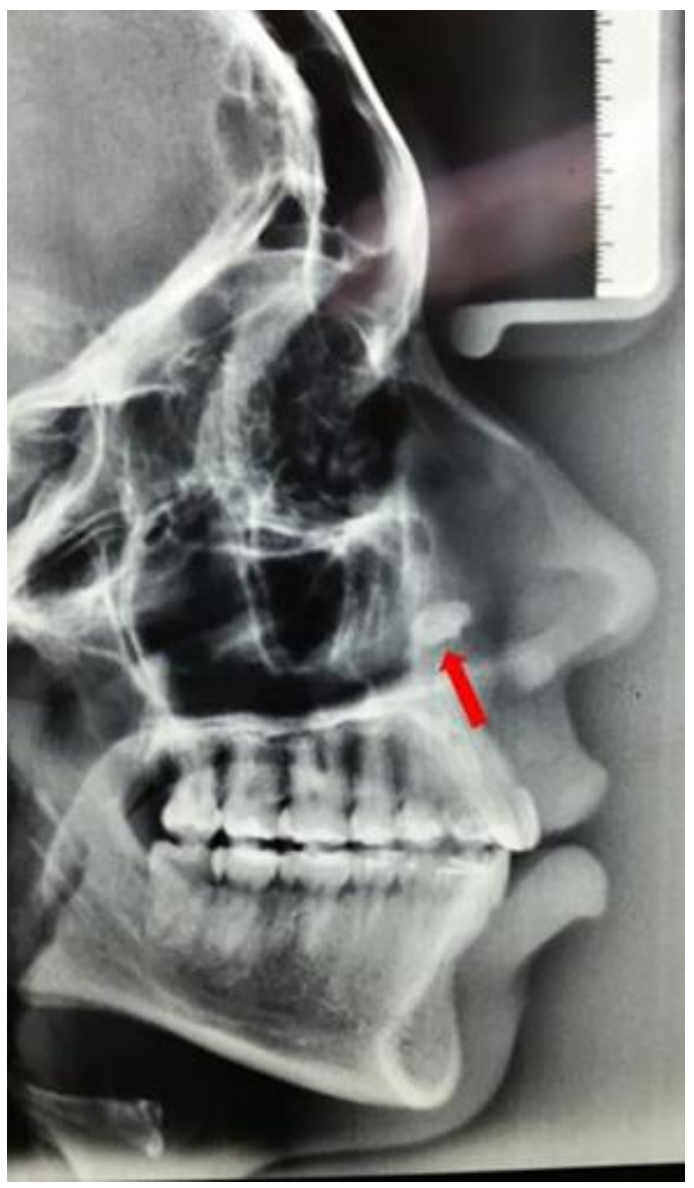

Figure 1: Lateral radiograph of the face showing the presence of an ectopic tooth in the lateral wall of the nasal cavity (red arrow).

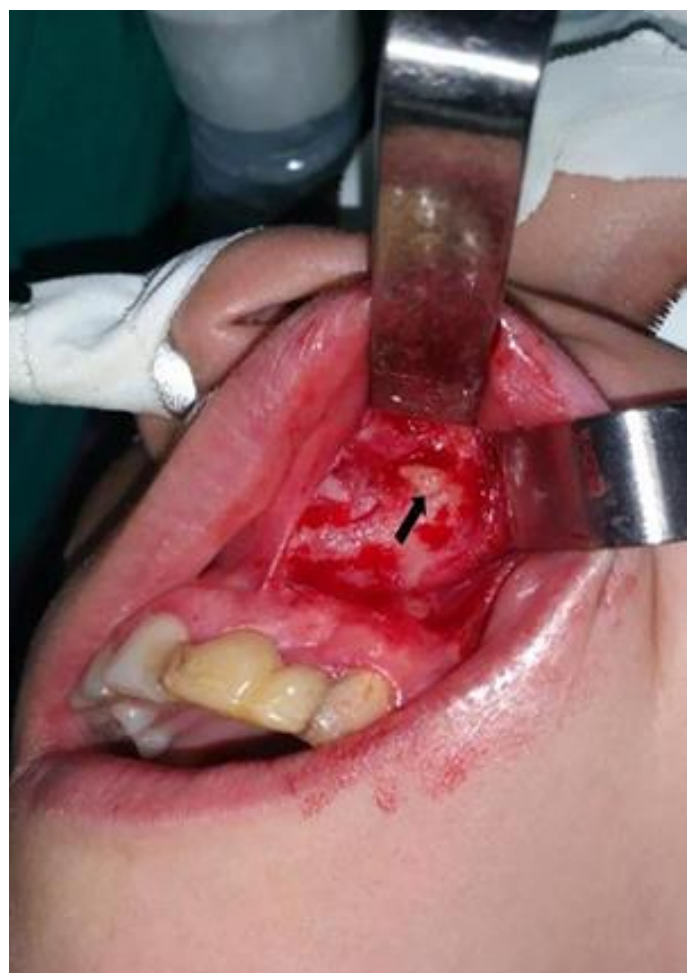

Figure 2. The position of the tooth on the lateral wall of the left nasal fossa (black arrow). 
The tooth was removed with the help of a straight Seldin lever, following the osteotomy performed at the periphery of the tooth with a $\mathrm{n}^{\circ} 701$ surgical drill. The detacher was positioned on the lateral wall of the nasal cavity to prevent movement of the tooth into the cavity.

After removal of the tooth, the surface was curetted, and the absence of a pericoronary hood was observed (Figures 3 and 4). Surgical site lavage was performed and the surgical wound was closed with polyglactin 910 resorbable suture $\left(\right.$ Vicryl $\left.^{\circledR} 4.0\right)$. We chose not to perform basal suture. The patient did not present immediate postoperative bleeding and was discharged the day after surgery.

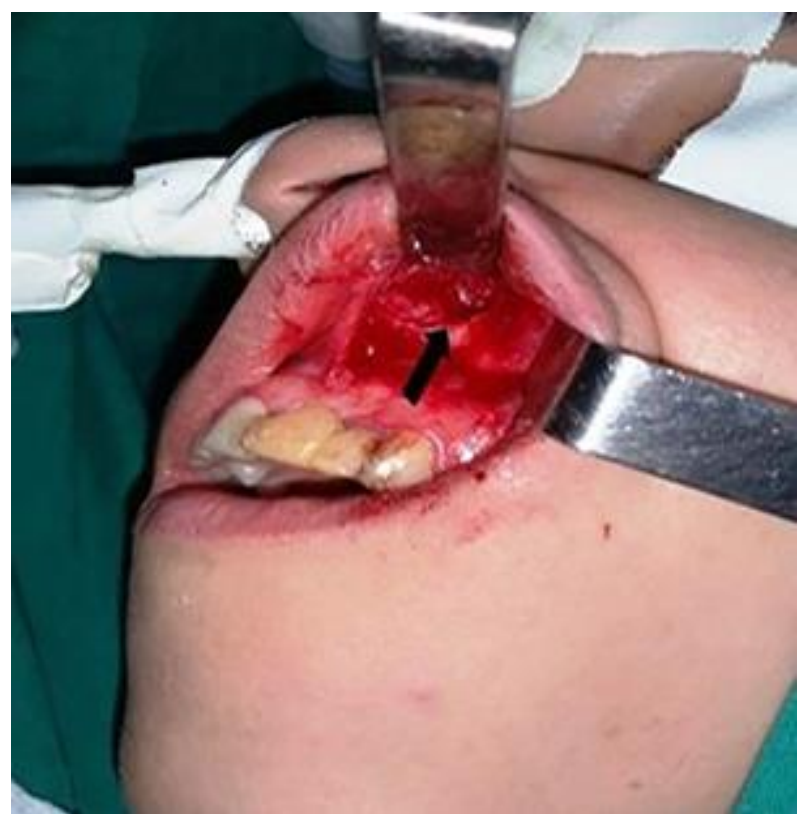

Figure 3: View after removal of the tooth from the nasal cavity (black arrow).

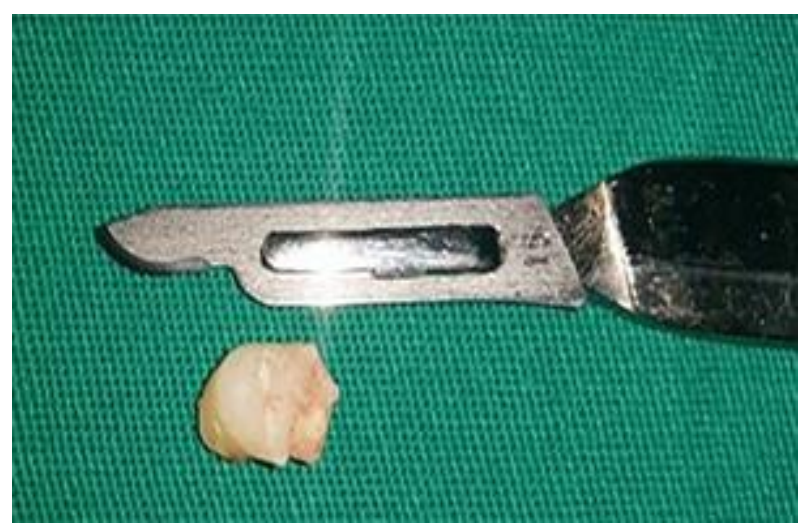

Figure 4: Tooth out of the cavity.

\section{DISCUSSION}

Ectopic teeth in the nasal cavity are especially rare compared to other locations. Their etiology is nonspecific and they require clinical study, investigation, diagnosis and a correct treatment choice $^{4}$. These ectopic teeth are found in the deciduous, permanent or supernumerary dentition, especially in children and more commonly involving the first dentition ${ }^{3}$, in contrast to the present case in which the ectopic tooth belonged to the permanent dentition due to a probable germ trauma of the permanent teeth caused by the deciduous dentition. They can arise in several locations of the face, among them the mandible, where they are rarely found in the mandibular orbital condyle and in the nasal fossa. In the maxilla, the most common sites of ectopic teeth are the palate and maxillary sinus ${ }^{3,4,6}$, while teeth in the nasal cavity are even rarer.

Their etiology is controversial; studies have suggested a relationship of these teeth with developmental alterations, such as palatine fissures, infections, trauma, cysts and obstruction of the permanent teeth due to the persistence of deciduous ones and bone tissues ${ }^{1,3,6}$. Trauma is the most common etiology in childhood. Ray et al. (2006) described idiopathic etiology as an etiological factor for ectopic teeth.

The age distribution of traumas in the dentition ranges from 1 to 12 years, the most prevalent age being that from the first to the third year ${ }^{3}$. After the identification of ectopic elements in the maxillofacial region, an investigation is necessary to determine possible causes and adjacent lesions. In the case reported here, due to the patient's history, trauma during childhood was believed to have been responsible for the displacement of the developing dental germ.

Although an intranasal tooth is not difficult to diagnose, it is easily ignored due to the absence of symptoms and to its variable clinical presentation. The diagnosis of intranasal teeth is made based on clinical and imaging analysis with the help of radiography, computed tomography, endoscopy and histological exams. An ectopic tooth in the lateral wall of the nasal cavity may be asymptomatic or present with symptoms such as nasal obstruction, suppuration, recurrent epistaxis, rhinitis, septal deviation, nasal fistula, chronic sinusitis, bad smell, facial pain, and headaches. When asymptomatic it is usually revealed only through routine clinical or radiological examination ${ }^{8,9}$. In the present case, the patient discovered the presence of the tooth by tomographic examination for placement of a graft and did not present any symptoms.

Radiographically, an ectopic tooth in the lateral wall of the nasal cavity appears as a dense radiopaque mass with characteristics similar to those of bone. However, the presence of a calcified intranasal mass may suggest other pathologies, such as bone sequestration, neoplasia, exostosis, radiopaque foreign body, fungal infection with calcification and rhinolith ${ }^{9}$. Clinically, an intranasal tooth may look as a white mass surrounded by granulation tissue or as a reddish mass surrounded by granulation tissue or nasal mucosa ${ }^{4}$. The correlation with the clinical examination is of extreme importance since it may help with the diagnosis.

Treatment for intranasal teeth depends on the 
presence or absence of symptoms. In the presence of symptoms, it is necessary to evaluate the position of the tooth and the potential lesions caused by the surgery ${ }^{9}$. When the condition is diagnosed in childhood, authors support the argument for early removal even in asymptomatic teeth in view of potentially serious sequelae, such as cavernous sinus thrombosis, because an intranasal tooth is situated in the so-called "danger triangle" region of the middle third of the face, where the veins and valves can drain into the intracranial space, and lead to severe complications ${ }^{10}$. In children, the extraction of these ectopic teeth should be performed when the roots of the permanent teeth are completely formed in order to minimize the risk of injury to the permanent tooth ${ }^{9}$. The patient reported here did not present painful symptoms, and the intervention was performed in adulthood.

According to Sammatino et al (2011), intranasal teeth can be removed by a transnasal access or through the palate. The transnasal access has been described and has been reported to be often less invasive, with the advantage of direct visualization under the nasal speculum support. However, this visualization may not be sufficient and therefore endoscopy has been recently used to remove intranasal teeth with minimally invasive surgeries ${ }^{8,10,11}$. The surgical approach is indicated to remove supernumerary intranasal teeth in the posterior region of the nasal cavity or teeth with large amounts of bone at their periphery. Herein, surgery was the method chosen for the treatment of an ectopic tooth. It was a simple procedure with no postoperative complications.

\section{CONCLUSION}

An ectopic tooth in the lateral wall of the nasal cavity is a clinical case that requires special attention and care. The diagnosis and planning of appropriate treatment are of extreme importance for the resolution of these rare and complex cases of ectopic teeth.

\section{ACKNOWLEDGEMENTS}

The authors thank to Mrs. E. Greene provided English editing of the manuscript.

\section{REFERENCES}

1. Verma RK, Bakshi J, Panda NK. Ectopic intranasal tooth: an unusual cause of epistaxis in a child. Ear Nose Throat J. 2012;91(6):242-44.

2. Gupta YK, Shah N. Intranasal tooth as a complication of cleft lip and alveolus in a four years old child: case report and literature review. Int J Paediatr Dent. 2001;11(3):221-24.

3. Thor AL. Delayed removal of a fully intruded primary incisor through the nasal cavity: a case report. Dental Traumatol. 2002;18(4):227-30.
4. Koçak HE, Özdamar K, Bilgi B, Aipayam H. Case report a rare cause of intranasal mass: bilateral ectopic nasal teeth. Iran J Otorhinolaryngol. 2017;29(94):287-89.

5. Van Essen TA, Van Rijswijk JB. Intranasal toothache case report. J Laryngol Otol. 2013;127(3):321-22.

6. Kim DH, Kim JM, Chae SW, Hwang SJ, Lee SH, Lee HM. Endoscopic removal of an intranasal ectopic tooth. Int $\mathrm{J}$ Pediatr Otorhinolaryngol. 2003;67(1):79-81.

7. Ray B, Singh LK, Das CJ, Roy TS. Ectopic supernumerary tooth on the inferior nasal concha. Clin Anat. 2006;19(1):68-74.

8. Zalagh M, Akhaddar A, Benariba F. Chronic rhinorrhea revealing an actinomycotic rhinolithiasis with ectopic tooth. Int $\mathrm{J}$ Oral Maxillofac Surg. 2012;41(3):297-99.

9. Moreano EH, Zich DK, Goree JC, Graham, SM. Nasal tooth. Am J Otolaryngol. 1998;19(2):124-26.

10.Sammatino G, Trosino O, Perillo L, Cioff A, Marenzi G, Mortellaro C. Alternative transoral approach for intranasal tooth extraction. J Craniofac Surg. 2011;22(5):1944-46.

11.Lee FP. Endoscopic extraction of an intranasal tooth: a review of 13 cases. Laryngoscope. 2001;111(6):1027-31.

\section{CONFLICTS OF INTERESTS}

The authors declare no conflicts of interests.

\section{CORRESPONDING AUTHOR}

\section{Amália Moreno}

amalia_moreno@yahoo.com.br
Received 20/02/2019

Accepted 24/05/2019 